\title{
Az orvostanhallgatók vakcinológiai tájékozottsága
}

\author{
Fehér Ágnes dr. ${ }^{1}$ - Fekete Mónika dr. ${ }^{1}$ \\ Varga János Tamás dr. ${ }^{2}$ - Horváth Ildikó dr..$^{1,2,3}$ \\ ${ }^{1}$ Semmelweis Egyetem, Általános Orvostudományi Kar, Népegészségtani Intézet, Budapest \\ ${ }^{2}$ Országos Korányi Pulmonológiai Intézet, Budapest \\ ${ }^{3}$ Emberi Erőforrások Minisztériuma, Egészségügyért Felelős Államtitkárság, Budapest
}

\begin{abstract}
Bevezetés: A védőoltásokkal szembeni bizalmatlanság már az orvosok körében is tapasztalható. Fontos, hogy a fiatal orvosgenerációk megfelelő tájékozottsággal rendelkezzenek, betegeiket meg tudják győzni az oltások hasznosságáról, maguk jó példát mutassanak e téren.

Célkitüzés: A tanulmány célkitûzése a Semmelweis Egyetem általánosorvostan-hallgatóinak vakcinológiai ismereteit, valamint a védőoltásokhoz való hozzáállásukat felmérni a 'Népegészségtan és preventív medicina' oktatása előtt és után. A kanyaró és a hepatitis B-vírus elleni védőoltások mellett hangsúlyt kapott a hallgatók véleménye az influenza elleni védőoltásról és hatékonyságáról.

Módszer: Az adatgyüjtés önkéntes résztvevőkkel, anonim, önkitöltéses kérdőívekkel történt. Az oktatás és az átoltottság közötti összefüggés igazolása Pearson-féle korreláció számításával és egytényezős varianciaanalízissel történt.

Eredmények: Tanulmányunkban rávilágítunk a vakcinológia oktatását követő ismeret- és attitúdváltozás mértékére. Az orvostanhallgatók tudása hiányos, negatív attitúdökkel rendelkeznek az influenza elleni oltással kapcsolatban. A válaszadók általánosságban hasznosnak tartották a védőoltásokat, azonban az influenza elleni vakcinát a kitöltóknek csak a kétharmada vélte fontosnak. A hallgatók influenzaátoltottsága oktatás előtt 6,5\%, az oktatást követően $24 \%$ volt. A statisztikai számítások igazolták az összefüggést az oktatás és az átoltottság mértékének emelkedése között. A hallgatók kétharmada $(67,8 \%)$ volt tisztában azzal, hogy az influenza elleni oltóanyagot járvány idején is be szabad adni. Meglepő módon a kézmosás fontosságának nagyobb szerepet tulajdonítottak a védőoltásnál az influenza megelőzésében.

Következtetések: Az oktatás jelentősége vitathatatlan a leendő orvosok szemléletének, felelősségtudatos magatartásának alakításában. Megbízható tudást kell szerezniük, hogy gyakorló orvosként meggyőzzék betegeiket a fertőző betegségek primer prevenciója leghatékonyabb eszközének igénybevételéről. Szemléletváltás szükséges, hogy a védőoltással - megszakítva a fertózési útvonalat - nemcsak a saját, de a környezetük, ezáltal a betegeik egészségének védelmét is szolgálják.
\end{abstract}

Orv Hetil. 2019; 160(30): 1193-1199.

Kulcsszavak: védőoltás, tájékozottság, hozzáállás, orvostanhallgató

\section{Medical students' knowledge on vaccinology}

Introduction: The mistrust of vaccinations is already experienced among physicians. It is important for physicians to be well informed, able to convince their patients of the usefulness of vaccinations and set good example for them in this field.

Aim: The aim of the study was to assess the vaccine knowledge and attitudes of the general medical students of Semmelweis University and their attitudes towards vaccinations before and after the education of 'Public Health and Preventive Medicine'. Emphasis was placed on the students' opinion on the vaccines against influenza, measles and hepatitis B virus and their effectiveness.

Method: Data collection was done with volunteer participants, using anonymous self-administered questionnaires. The relationship between education and vaccination coverage was proved by calculating Pearson's correlation and one-way analysis of variance.

Results: The knowledge of medical students is incomplete, with negative attitudes towards vaccination against influenza. Generally, respondents found the vaccines useful, but only two-thirds of them considered the influenza vaccine to be important. Students had $6.5 \%$ flu vaccination coverage before education, and $24 \%$ after education. Two-thirds $(67.8 \%)$ of the students were aware that the flu vaccine could be given during an epidemic. Surprisingly, the importance of hand washing has been given a greater role in the primary prevention of influenza than flu vaccine. 
Conclusions: Education plays an important role in shaping the attitudes and responsible behaviour of future physicians. They need to acquire reliable knowledge to persuade their patients as practitioners to use the most effective means of primary prevention of infectious diseases. A change of attitude is needed to stop the route of infection through vaccination, to protect not only their own health but also that of their environment and thus of their patients.

Keywords: vaccination, awareness, attitude, medical student

Fehér Á, Fekete M, Varga JT, Horváth I. [Medical students’ knowledge on vaccinology]. Orv Hetil. 2019; 160(30): 1193-1199.

(Beérkezett: 2019. január 29.; elfogadva: 2019. február 12.)

\begin{abstract}
Rövidítések
ANOVA $=($ analysis of variance $)$ varianciaanalízis; $\mathrm{CDC}=(\mathrm{US}$ Centers for Disease Control and Prevention) Amerikai Járványügyi és Betegségmegelőzési Központ; $\mathrm{COPD}=($ chronic obstructive pulmonary disease) krónikus obstruktív tüdőbetegség; GOLD = (global initiative for chronic obstructive lung disease) globális kezdeményezés krónikus obstruktív tüdőbetegség esetén; $\mathrm{KSH}=$ Központi Statisztikai Hivatal; MMR = morbilli (kanyaró)-mumpsz-rubeola elleni védőoltás; nnv = „nem nélkül válaszoló” (a kérdőívet kitöltő nem adta meg a nemét); WHO = (World Health Organization) Egészségügyi Világszervezet
\end{abstract}

A védőoltások miatti bizalmatlanság miatt sajnos egyre aggasztóbb a helyzet mind a lakosság, mind az egészségügyi szakemberek körében [1]. Az orvostanhallgatók különösen fontos szerepet játszanak a különböző vakcinák elfogadtatásában mind a veszélyeztetett populációk, mind a lakosság körében [2]. Mivel az internet és a szociális média egyre fontosabb szerepet tölt be a betegek tájékozódásában - ahol különböző, néha félrevezető információkat szerezhetnek -, az orvosoknak készen kell állniuk arra, hogy megfelelően válaszoljanak kérdéseikre, aggályaikra a védőoltások körében is [3]. Gyakran említik az egészségügyi szakemberek a nem megfelelő orvosi képzést annak magyarázatára, hogy néhány gyakorló orvos miért nem oltja be a betegeit $[4,5]$. Fontos előrelépést jelentene a leendő orvosok vakcinológiai oktatásának értékelése, mivel jelenleg nagyon kevés adat áll rendelkezésre az orvostanhallgatók képzéséről ezen a területen $[5,6]$.

Az influenza elleni vakcinázás védi mind az egészségügyi dolgozót, mind a betegeket. Ez egyben a legköltséghatékonyabb megelőző intézkedés [7], azonban az egészségügyi szakemberek influenza elleni átoltottsági aránya továbbra sem optimális. Az Európai Unió adatai szerint mindössze 6-54\%-os az egészségügyben dolgozók influenza elleni átoltottsága [8], ezért a betegek biztonsága érdekében különösen fontos intézkedés lenne az átoltottsági arány növelése.

Az influenza elleni vakcinázás évente javasolt, de nem kötelező a WHO ajánlása szerint [9]. Az orvostanhallga- tók világszerte nagyon alacsony arányban vannak átoltva, mindössze $5,9 \%$ és $48 \%$ közötti az arány $[10,11]$. Az egyik legmagasabb átoltottságot egy ausztrál esettanulmányban említették, ahol a hallgatók 47,5\%-a kapta meg az influenza elleni oltást [12].

Az Amerikai Járványügyi és Betegségmegelőzési Központ (US Centers for Disease Control and Prevention; CDC) minden 6 hónapos és idősebb személy számára évente szezonális influenza elleni védőoltást javasol, különös tekintettel a veszélyeztetett populációkra, ideértve a 65 év feletti felnőtteket, a kisgyermekeket, a várandós nőket és a krónikus betegségben szenvedő betegeket, akiknek az influenzavírus súlyos betegséget vagy akár halálos szövődményt is okozhat [13]. A nemzetközi COPD-ajánlás (GOLD) szerint az influenza elleni vakcináció a legerősebb (A) evidenciával csökkenti a súlyos tünetek kialakulását. Ezen ajánlások ellenére az Amerikai Egyesült Államok szezonális influenzavakcinázási aránya továbbra is nagyon alacsony, becslések szerint a felnőttek mindössze 41\%-a kapja meg az oltást; ez az elmúlt hét évben csupán 3\%-os növekedést mutatott, holott a célkitüzés 2020-ra a 70\%-os átoltottsági arány lenne [14].

A WHO adatai szerint az influenzavírus elleni oltóanyag az oltott egészséges felnőttek 70-90\%-ában bizonyul hatékonynak a betegség megelőzésében. A védőoltás az idős emberek körében a kórházi felvételek számát 25-39\%-kal, a halálozási gyakoriságot 35-57\%-kal csökkentheti. Mivel a Magyarországon forgalomban lévő influenzavakcinák kizárólag inaktivált vírust vagy annak csupán egy meghatározott részét tartalmazzák, így nem okozhatnak influenzás megbetegedést [15].

\section{Célkitüzés}

Vizsgálataink arra keresték a választ, hogy az orvostanhallgatók mennyire tájékozottak a védőoltásokkal kapcsolatban, széles körúek-e az ismereteik, illetve milyen a hozzáállásuk. Kiemelten az influenza elleni vakcinára, annak vélt hatékonyságára kérdeztünk rá, valamint kíváncsiak voltunk az átoltottság mértékére is. Tanulmányunkban rávilágítunk a vakcinológiaoktatást követő ismeret- és attitüdváltozás mértékére is. 


\section{Módszer}

Az adatgyưjtés önkéntes résztvevőkkel, anonim módon, önkitöltéses kérdőívek segítségével történt. A vakcinológiával kapcsolatos, oktatás előtti ismeretet és hozzáállást papíralapú kérdőívekkel, a Semmelweis Egyetemen a 2017/2018-as tanév II. szemeszterében, a negyedéves általánosorvostan-hallgatók körében (a továbbiakban: 1 . csoport) végeztük. A Semmelweis Egyetemen a 'Megelőző orvostan és preventív medicina' tantárgy oktatása két félév alatt történik: az első félévben nem esik szó a védőoltásokról, csak a második félévben. Az oktatás után közel egy évvel, 2018 decemberében az ötödéves hallgatóktól (a továbbiakban: 2. csoport) az interneten elérhető elektronikus, tartalmát tekintve azonos kérdőíven kértünk választ. A kerdoivem.hu weboldalt e-mailen keresztül elküldött link segítségével érhették el. A vizsgálat két keresztmetszeti adatfelvétellel történt, semmilyen biztosíték nem volt a válaszadók körében a személyi azonosságra.

A kérdőív a személyes adatok közül csak a hallgatók nemére vonatkozóan kért információt, ezen túlmenően kizárólag a védőoltásokkal kapcsolatos ismeretekre utaló kérdéseket tartalmazott. Az 1. csoport tagjaival személyes volt a kapcsolatfelvétel, míg a 2. csoport tagjai szélesebb körból kerültek ki: egymásnak továbbították a kérdőív elérését biztosító linket e-mailen keresztül. Az interneten keresztül történt válaszadás esetében nem volt lehetőség kérdés kihagyására, hisz ebben az esetben a rendszer nem engedte tovább a kitöltőt a következő kérdésre. Ebből eredt az a lényeges különbség, hogy a nemek a 2. csoport esetében minden esetben rögzítésre kerültek. A 10 vakcinológiai kérdésre előre megadott válaszlehetőségekkel lehetett felelni (igen/van, nem/ nincs, nem tudom). A kérdőív kitöltése előtt a hallgatók részletes tájékoztatást kaptak a felmérés céljáról, idejéról, az anonim és összesített adatfeldolgozásról, a kutatás lényegéről.

\section{Statisztikai analízis}

Az adatok feldolgozása százalékos megoszlások alapján, az Excel 2016 táblázatkezelő szoftver (Microsoft Corporation, Redmond, WA, Amerikai Egyesült Államok) adatelemző bővítményének segítségével történt. A statisztikai analízis során az oktatás és az influenza elleni átoltottság közötti összefüggést Pearson-féle korreláció számításával és egytényezős varianciaanalízissel (ANOVA) igazoltuk. Az eredményeket $\mathrm{p}<0,05$ érték esetén tekintettük szignifikánsnak.

\section{Eredmények}

Oktatás előtt a kérdőívet a 2017-2018-es tanév II. félévének elején 278 fó (a negyedéves hallgatók 73\%-a), a 2018-2019-es tanév I. félévének végén 200 fö (az ötödéves hallgatók 55\%-a), összesen 478, az általános orvos-
1. táblázat |A nemek aránya a két vizsgálat során

\begin{tabular}{lccc|cc}
\hline & \multicolumn{3}{c|}{ 1. csoport } & \multicolumn{2}{c}{ 2. csoport } \\
\cline { 2 - 6 } & Válaszadó & $\% *$ & $\% * *$ & Válaszadó & $\%$ \\
\hline Férfi & 57 & 20,5 & 32,2 & 75 & 37,5 \\
Nö & 120 & 43,2 & 67,8 & 125 & 62,5 \\
\multirow{2}{*}{ nnv } & 101 & 36,3 & - & 0 & 0,0 \\
\hline Összesen & 278 & 100,0 & 100,0 & 200 & 100,0 \\
\hline Férfi/nó & 0,475 & - & - & 0,600 & \\
\hline
\end{tabular}

*Az összes válaszadóhoz viszonyított százalék

**A nemüket megadók számához viszonyított százalék nnv $=$ „Nem nélkül válaszoló”

tudományi karra járó hallgató töltötte ki. Az 1. csoport hallgatóinak 36,3\%-a (101 fó) nem adta meg a nemét. $\mathrm{Az}$ ismert nemi identitású válaszadók közel harmada $(32,2 \%)$ volt férfi. A 2 . csoportban mindenki beírta a nemét, közülük $37,5 \%$ volt férfi (1. táblázat).

\section{Oltottsági státusz}

A válaszadók 94,7\%-ának (a férfiak 93,9\%-ának, a nők 95,1\%-ának) van oltási könyve. A legjobb arány $(97,0 \%)$ a nemüket meg nem adók körében volt tapasztalható. Az összes hallgató 3,1\%-ának nincs oltási könyve, 1,7\% pedig nem tudta megmondani, hogy van-e. A két csoport adatai között lényeges eltérés nem mutatkozott.

Az összes hallgató 15,9\%-a, az 1. csoport ötöde $(19,3 \%)$, a 2 . csoport tizede $(11,5 \%)$ nem kapta meg, vagy nem tudta megmondani, hogy vajon megkapta-e a kanyaró elleni mindkét oltást. A nemmel válaszolók mindössze $0,4 \%$-ot tettek ki. A válaszban a férfiak voltak kissé bizonytalanabbak: a férfiak 14,4\%-a, a nók 12,7\%-a nem tudott érdemben válaszolni a kanyaróval szembeni védettségüket illetően.

A hepatitis $\mathrm{B}$-vírus elleni védőoltást a válaszadó hallgatók 97,3\%-a megkapta. Az 1. csoportban a nők 99,2\%-a, a férfiak 96,5\%-a, a „nem nélkül válaszolók” 95,1\%-a számolt be arról, hogy az oltást megkapta. Az oktatás után válaszolók között kisebb különbségek voltak tapasztalhatók: a férfiak 98,7\%-a, a nők 97,6\%-a oltott státuszú.

A hallgatók influenza elleni átoltottsága igen alacsony. Az oktatást megelőzően mindössze 6,5\%-uk volt beoltva: a férfiak 7,0\%-a, nók 6,7\%-a, nemüket meg nem adók (továbbiakban: nnv, azaz „nem nélkül válaszoló”) 5,9\%-a. Az oktatást követően ez lényegesen növekedett, de még mindig nagyon elmaradt a kívánt átoltottsági szinttől: összességében a beoltottak száma a válaszadók negyedét sem érte el $(24 \%)$. A férfiak meggyőzhetőbbnek tüntek ezen a téren, átoltottságuk nagyobb mértékben, 23,7\%kal, míg a nőké 13,3\%-kal emelkedett az oktatást követően (1. ábra).

Az oltottsági hajlandóság 31 fóvel, 17,75\%-ot növekedett a 'Népegészségtan és preventív medicina' tantárgy 


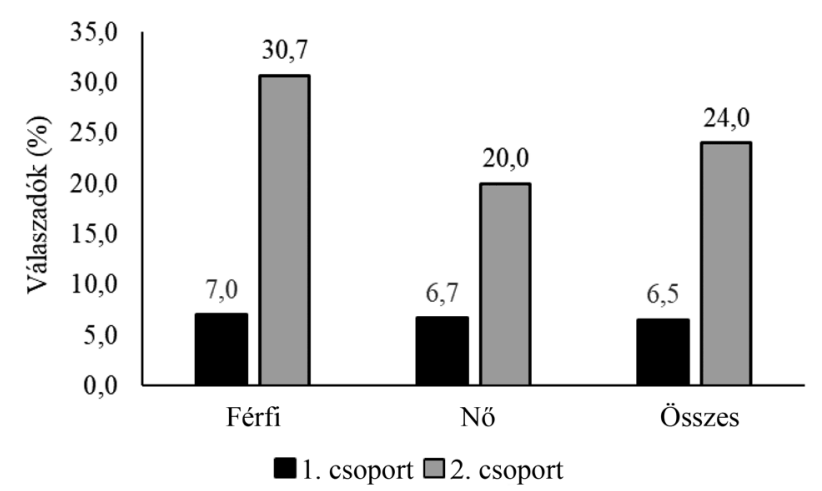

1. ábra

Influenzaátoltottság a két csoportban, nemek szerint $\left(\mathrm{N}_{1}=272\right.$ $\mathrm{N}_{2}=200$ )

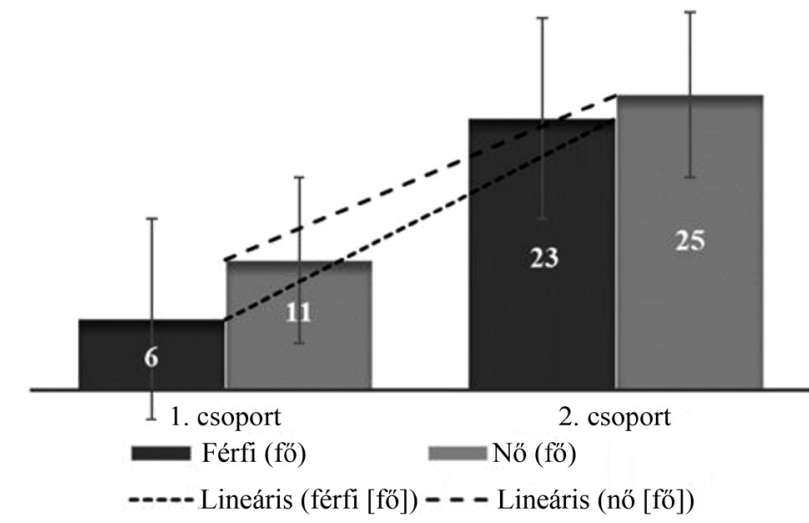

2. ábra

Az influenzavírus ellen beoltottak számának változása nemenként a két csoportban

felvétele után egy évvel. Ok szerepét betöltő minőségi ismérv volt, hogy a hallgató hasznosnak tartja-e az influenza elleni védőoltást (igen $=1 ; n e m=2$ ), illetve hogy a hallgató negyedéves vagy ötödéves-e. Hipotézisünk szerint az okozat az volt, hogy a hallgató beoltatja-e magát influenzavírus ellen vagy sem (oltottsági állapot: igen = $1 ;$ nem $=2$ ). A varianciaanalízis (ANOVA) statisztikailag szignifikáns összefüggést mutatott a hallgatók influenza ellen történt átoltottsága és az oktatás között ( $\mathrm{p}=$ 0,$000000058 ; 2$. ábra).

Meglepő módon a válaszadók 4,0\%-a nem tudta, megkapta-e a szezonális influenza elleni védőoltást. Az oktatás előtti hallgatói csoportban $5,8 \%$, az oktatás utániban már csak 1,5\% nem volt tisztában saját oltási státuszával.

\section{Ismeret az influenzáról}

A hallgatók jelentős része még a járványtan oktatása után sem kezelte az influenzabetegséget kellő súllyal. Számukra - egészséges fiatal felnőttek számára - viszonylag könnyen átvészelhetố a betegség. Mindössze 70,7\%-uk volt tisztában azzal, hogy az influenzavírus súlyos megbetegedéshez vezethet, többen megjegyzésben közölték véleményüket: csak idős beteg számára okozhat veszélyes állapotot. Az 1. csoport 67,6\%-a (férfi: 71,9\%, nő: $70,0 \%$, „nem nélkül válaszoló”: $62,4 \%)$ adott helyes vá-

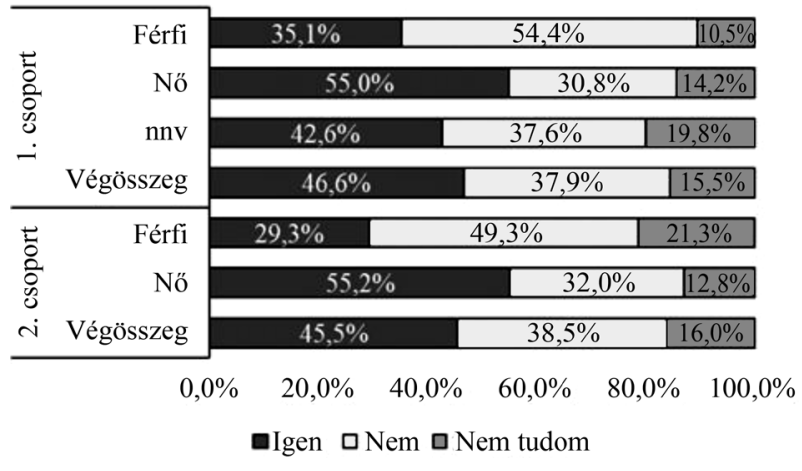

3. ábra

Válaszok a kézmosásra vonatkozó kérdésre, mely szerint az influenza megelózésének leghatékonyabb módja a kézmosás (a helyes válasz: nem)

laszt. Ez az arány a 2. csoportban csak kissé lett magasabb, 75\% (férfi: 78,7\%, nő: 72,8\%). A hallgatók közel negyede $(23,6 \%)$ enyhe betegségnek tartotta az influenzát, míg 27 válaszadó $(5,6 \%)$ nem tudott dönteni a kérdésben.

A kézmosás fontosságáról, a betegségek megelőzésében betöltött szerepérôl a hallgatók többször, több fórumon is hallottak már. Ezért volt sokuknak nehéz feladat eldönteni, vajon a kézmosásnak elsődleges szerepe van-e az influenza megelózésében. Sajnos igen magas arányban, a hallgatók közel fele (46,1\%-uk) a kézmosást - helytelenül - hasznosság tekintetében az oltás elé helyezte! Mindössze 38,2\%-uk vélte úgy, hogy nem a kézmosás a leghatékonyabb védekezési módszer az influenza ellen. Meglepóen sokan (15,7\%) nem jutottak döntésre a kérdésben. A férfiak kb. fele megfelelő választ adott, ugyanakkor a második csoport válaszaiban a jó választ adók aránya 54,4\%-ról 49,3\%-ra csökkent; bár a rossz választ adók száma is csökkent, ezzel párhuzamosan a bizonytalanok aránya duplázódott meg (10,5\%-ról $21,3 \%$-ra nőtt). Ezzel szemben a nók válaszainak aránya nem változott jelentősen egy év múlva: a jó, a rossz és a bizonytalan válaszok aránya gyakorlatilag azonos maradt (3. ábra).

\section{Hozzáállás, illetve tájékozottság az influenzavírus elleni oltással kapcsolatosan}

Általános kérdésként felvetve szinte minden hallgató $(99,4 \%)$ hasznosnak tartotta a védőoltásokat. Az 1. csoport hallgatói közül csak a „nem nélkül válaszolók” nem feleltek 100\%-ban igennel, két fő (2\%) „nem tudom” választ jelölt meg. A 2. csoportban egy nó kivételével, aki nem tudott állást foglalni, a többiek mind a hasznosság mellett voksoltak.

Az influenza elleni védőoltásra kérdezve a hasznosság megítélése lényegesen csökkent. Az l. csoportban a férfiak 78,9\%-a, a nők 70,8\%-a, a „nem nélkül válaszolóknak" azonban mindössze a 64\%-a tartotta hasznosnak az influenza primer prevenciójának ezt a módszerét. Összességében a hallgatók $70 \%$-a vélekedett pozitívan 


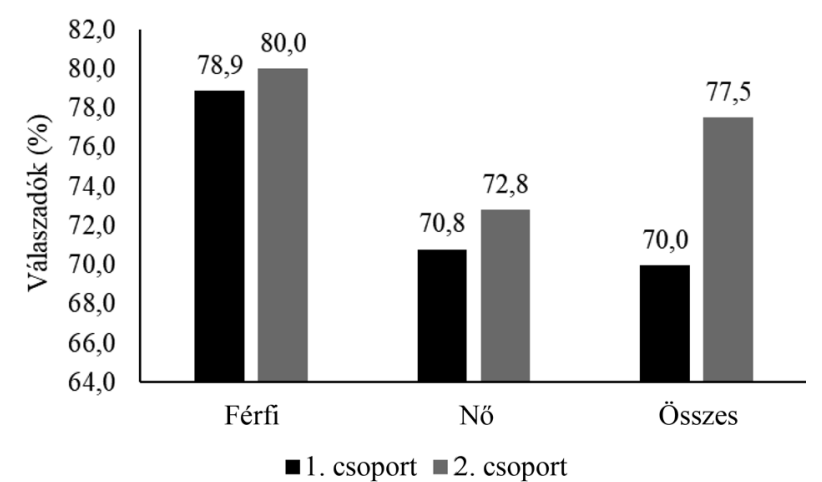

4. ábra $\mid$ Az influenzavírus elleni oltást hasznosnak ítélők nemek szerint

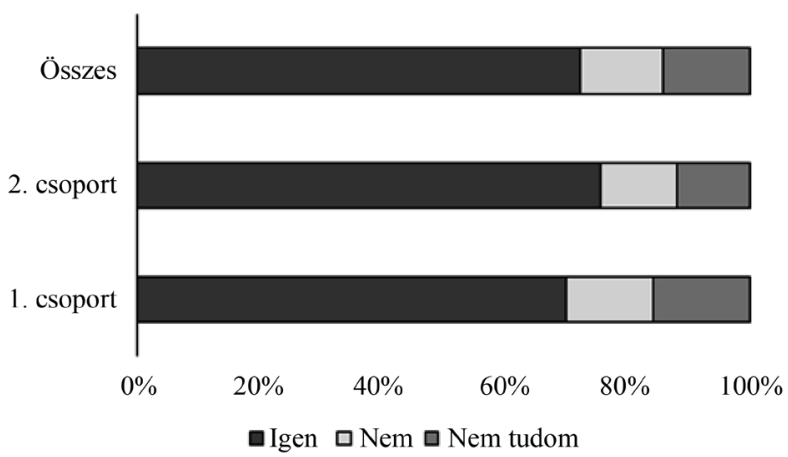

5. ábra

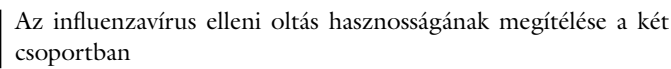

erről az oltásról, és az oktatás után sem változott lényegesen a megítélése, a megítélt hasznosság mindössze néhány százalékot emelkedett $(77,5 \%)$ (4. ábra). Az oltás hasznosságát cáfolók és a bizonytalanok aránya mindkét csoportban közel azonos volt: az 1. csoportban 14,1\% „nem” és 15,9\% „nem tudom” válasz érkezett, a 2. csoportban a hallgatók 12,5\%-a jelölt a „nem”-re, és 12,0\% a „nem tudom” válaszlehetőségre (5. ábra).

Pearson-féle korrelációs analízissel pozitív összefüggést találtunk az oktatás, valamint az oltás hasznosnak ítélése, illetve az influenza elleni átoltottság növekedése között. Az 1. csoport átoltottsági aránya és az influenza elleni védőoltás hasznosnak ítélése között a korreláció pozitívnak bizonyult, azonban csak gyenge kapcsolat állt fenn a két minőségi ismérv között. Egy évvel később (2. csoport) a korreláció kapcsolati erósödést mutatott $(\mathrm{r}=$ 0,22 ). Aki az oktatás után hasznosnak ítélte meg az influenza elleni védőoltást, nagyobb eséllyel oltatta be magát.

Nagy bizonytalanság mutatkozott az influenza elleni oltást követő eseményeket illetően. Arra a kérdésre, hogy igaz-e az az állítás, mely szerint az influenza elleni oltás nem okoz influenzamegbetegedést, a válaszadók kevesebb, mint fele adott helyes választ (48\%). Az 1. csoport hallgatói közül a férfiak $61,4 \%$-a, a nők $40 \%$-a válaszolt megfelelően. A 2. csoportban sem születtek sokkal jobb eredmények, mert itt a férfiak mindössze 64\%-a, a nők

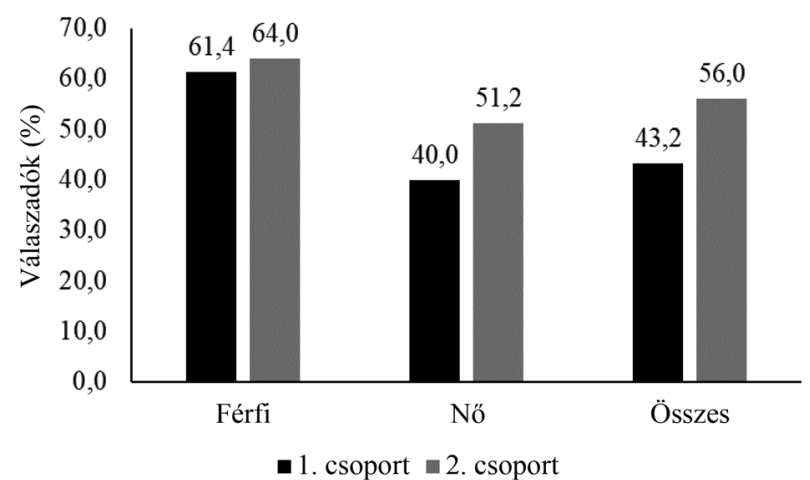

6. ábra $\mid \begin{aligned} & \text { A helyes válaszok aránya, miszerint az oltás nem okoz influenza- } \\ & \text { megbetegedést }\end{aligned}$

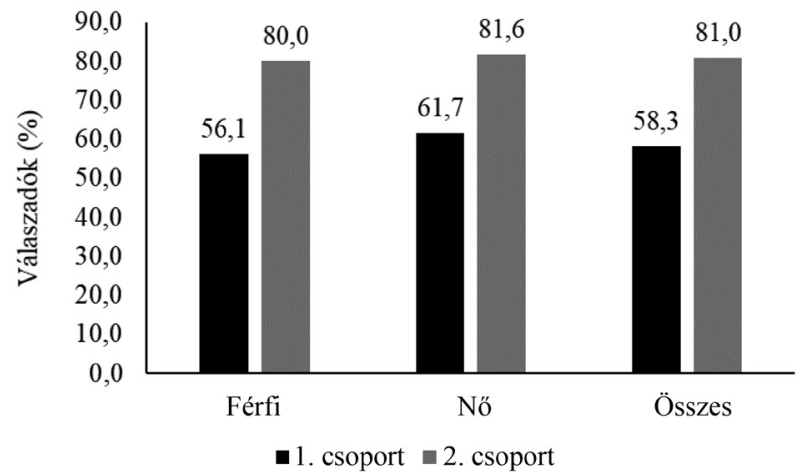

7. ábra $\mid$ A helyes válaszok arányának változása az oltóanyag járvány ide jén történő alkalmazhatóságát illetően

56\%-a tudta, hogy az oltás következtében nem lesz influenzás a beoltott (6. ábra). A „nem nélkül válaszoló” hallgatók igen alacsony százaléka $(36,6 \%)$ adott megfelelő választ.

A hallgatók kétharmada $(67,8 \%)$ volt tisztában azzal, hogy az influenza elleni oltóanyagot járvány idején is be szabad adni. Ennek a kérdésnek a megválaszolásakor a nemek között nem mutatkozott jelentős véleménykülönbség sem az 1. csoportban (férfi: $56,1 \%$, nő: $61,7 \%$ ), sem a 2 . csoportban (férfi: $80 \%$, nő: $81,6 \%$ ). Feltűnő volt a helyes válaszok arányának emelkedése azonban mind a férfiak, mind a nők esetében az oktatást követően (férfiak: 23,9\%, nók: 19,9\%) (7. ábra).

\section{Megbeszélés}

A kötelező védőoltások, ezen belül az MMR (kanyaró, mumpsz, rubeola elleni) védőoltás átoltottsága 98-99\%os [16-19], ez tükröződött a hallgatók válaszaiban is. Jó az átoltottsági arány a hepatitis B-vírus ellen is [19], ennek oka részben az oltás kötelező volta, másik oka, hogy ezt a betegséget a maga súlyával kezelik, tisztában vannak a betegség következményeivel.

Mind az orvosok, mind a lakosság körében a védőoltással megelőzhető megbetegedések közül az influenza váltja ki a legtöbb ellenállást, vitát. Ez leképződött ebben a vizsgálatban is: az orvostanhallgatók többnyire pozitív 
hozzáállást tanúsítanak általában az oltásokhoz, azonban az influenzavakcina elfogadását továbbra is akadályozzák a téves elképzelések. A KSH adatai szerint a 2017. év eleji jelentős halálozási többlet hátterében - a 2015. évi folyamatokhoz hasonlóan - most is a tetőző influenzajárvány állhatott [20]. A szakirodalomban több tanulmány rámutat arra, hogy ha az orvos be van oltva szezonális influenza ellen, akkor a betegek is nagyobb valószínúséggel kérik az oltóanyagot [21-25]. A jelen vizsgálatban az átoltottság aránya az 1 . csoportban $6,5 \%$, míg a 2. csoportban $24 \%$ volt, ami összhangban van más európai orvostanhallgatók körében végzett hasonló jellegü kutatásokkal $[10,26]$. Bár fontos, hogy az egészségügyi személyzet ne adjon át kórokozókat a betegeknek, hiszen az ápoltak a veszélyeztetett lakossági csoportba tartoznak, az orvostanhallgatóknak csak a töredéke oltatta be magát influenza ellen. A második csoportban már a négyszeresére nőtt ugyan az átoltottság, ez azonban a betegek védelme szempontjából nem elégséges. Nagyobb hangsúlyt kell fektetni az egészségügyi dolgozók felelősségére ezen a téren. A hallgatók körében tapasztalt tévhitek leképezik az orvostársadalomban is hallható oltásellenes hangokat. Fontos, hogy a védőoltások az oktatásban megkapják a szerepüknek megfelelő hangsúlyt, a hiedelmeket, téves információkat felváltsa a XXI. századnak megfelelő tudás.

Bár az influenza elleni védőoltás nem ad 100\%-os védelmet, tudatosítani kell azt a tényt is, melyet számos tanulmány igazolt, miszerint az oltottak közül feleannyian (36-70\%) szorultak kórházi kezelésre és feleannyi (13-80\%) haláleset fordult elő közöttük az oltásban nem részesülőkhöz képest [27]. Az oltásvédelemben nem részesült személyek körében a tüdőgyulladás és az influenza kórházi kezelési aránya kétszer olyan magas volt [28]. A szövődmények előfordulása is csökkent mind a 18-64 évesek körében, mind a 65 évnél idősebbeknél (39\%). Az első alkalommal oltottak esetében 47\%-kal (0,2-72\%), az előző évben is immunizáltak esetében 58\%-kal (4-81\%) mérséklődött a szövődmények előfordulási gyakorisága [27].

Az oltás védőhatását a krónikus népbetegségek esetében számos tanulmány, eset-kontroll vizsgálat igazolta. Az oltottak között kevesebb kórházi ellátást igénylő vagy fatális kimenetelü cardiovascularis megbetegedés (szívinfarktus, stroke) fordult elő járvány idején, mint az oltásban nem részesültek között [29, 30].

Tanulmányunk korlátai közt meg kell említenünk a viszonylag kis elemszámot és azt, hogy csak a Semmelweis Egyetem hallgatóit kérdeztük meg. További kutatásra van szükség ahhoz, hogy feltárjuk, vajon az oltóanyag hatékonyságának ismerete befolyásolja-e az orvostanhallgatókat a szezonális influenza elleni oltás felvételében. Rávilágítottunk az orvostanhallgatók vakcinológiai oktatásának jelentőségére is, hiszen a védőoltás mint primer prevenció a lehető legköltséghatékonyabb intézkedés a fertőző betegségek megelőzésére. A hallgatókat ösztönözni szükséges az előadások és a gyakorlatok keretein belül tájékozottságuk bővítésére, ami jelentősen hozzájárulhat a negatív attitűdök kedvező irányú formálásához.

Anyagi támogatás: A szerzók a cikk megírása, illetve a kutatómunka során anyagi támogatásban nem részesültek.

Szerzői munkamegosztás: F. Á.: A kérdőív szerkesztése, a kérdőívek feldolgozása, értékelése, irodalomkutatás, cikkírás. F. M.: Az elektronikus kérdőív kialakítása, irodalomkutatás, cikkírás, a statisztika elkészítése. V. J. T.: A kézirat megszövegezése, ellenőrzése, végső formába öntése. H. I.: A kutatás felügyelete, a statisztika ellenőrzése. A cikk végleges változatát valamennyi szerző elolvasta és jóváhagyta.

Érdekeltség: A szerzőknek nincsenek érdekeltségeik.

\section{Köszönetnyilvánítás}

A szerzők ezúton fejezik ki köszönetüket $d r$. Molnár Zsuzsanna föorvosnőnek az alapkérdőív kidolgozásáért és rendelkezésre bocsátásáért, valamint a negyed- és ötödéves orvostanhallgatóknak, akik lelkiismeretesen kitöltötték a kutatás kérdőívét.

\section{Irodalom}

[1] Strelitz B, Gritton J, Klein EJ, et al. Parental vaccine hesitancy and acceptance of seasonal influenza vaccine in the pediatric emergency department. Vaccine 2015; 33: 1802-1807.

[2] Flicoteaux R, Pulcini C, Carrieri P, et al. Correlates of general practitioners' recommendations to patients regarding vaccination for the 2009-2010 pandemic influenza $(\mathrm{A} / \mathrm{H} 1 \mathrm{Nl})$ in France: implications for future vaccination campaigns. Vaccine 2014; 32: 2281-2287.

[3] Yaqub O, Castle-Clarke S, Sevdalis N, et al. Attitudes to vaccination: a critical review. Soc Sci Med. 2014; 112: 1-11.

[4] Larson HJ, Jarrett C, Eckersberger E, et al. Understanding vaccine hesitancy around vaccines and vaccination from a global perspective: a systematic review of published literature, 20072012. Vaccine 2014; 32: 2150-2159.

[5] Sarnquist C, Sawyer M, Calvin K, et al. Communicating about vaccines and vaccine safety: what are medical residents learning and what do they want to learn? J Public Health Manag Pract. 2013 ; 19: 40-46.

[6] Vorsters A, Tack S, Hendrickx G, et al. A summer school on vaccinology: responding to identified gaps in pre-service immunisation training of future health care workers. Vaccine $2010 ; 28$ : 2053-2059.

[7] Burls A, Jordan R, Barton P, et al. Vaccinating healthcare workers against influenza to protect the vulnerable - is it a good use of healthcare resources? A systematic review of the evidence and an economic evaluation. Vaccine 2006; 24: 4212-4221.

[8] Kassianos G. Willingness of European healthcare workers to undergo vaccination against seasonal influenza: current situation and suggestions for improvement. Drugs Context 2015; 4: 212268 .

[9] World Health Organization. Influenza (seasonal). 6 November 2018. Available from: https://www.who.int/en/news-room/ 
fact-sheets/detail/influenza-(seasonal) [accessed: December 29, 2018].

[10] Betsch C, Wicker S. E-health use, vaccination knowledge and perception of own risk: drivers of vaccination uptake in medical students. Vaccine 2012; 30: 1143-1148.

[11] Mena G, Llupià A, García-Basteiro AL, et al. Educating on professional habits: attitudes of medical students towards diverse strategies for promoting influenza vaccination and factors associated with the intention to get vaccinated. BMC Med Educ. 2013; 13: 99

[12] Kelly DA, Macey DJ, Mak DB. Annual influenza vaccination. Uptake, barriers, and enablers among student health care providers at the University of Notre Dame Australia, Fremantle. Hum Vaccin Immunother. 2014; 10: 1930-1934.

[13] Grohskopf LA, Sokolow LZ, Broder KR, et al. Prevention and control of seasonal influenza with vaccines: recommendations of the Advisory Committee on Immunization Practices - United States, 2016-17 influenza season. MMWR Recomm Rep. 2016; 65: 1-54.

[14] Centers for Disease Control and Prevention. Flu vaccination coverage, United States, 2015-16 influenza season. Atlanta, GA, 2016. Available from: https://www.cdc.gov/flu/fluvaxview/ coverage-1516estimates.htm [accessed: December 29, 2018].

[15] National Center for Epidemiology. About influenza in general. Consumer Information. [Országos Epidemiológiai Központ. Az influenzáról általában. Lakossági tájékoztató.] Budapest. Available from: http://www.oek.hu/oek.web?nid=815\&pid=1 [accessed: January 5,2019 .] [Hungarian]

[16] World Health Organization. Immunization, vaccines and biologicals. 15 July 2018. Available from: https://www.who.int/ immunization/monitoring_surveillance/en/ [accessed: January $5,2019]$.

[17] The World Bank. Immunization, measles (\% of children ages 12-23 months). Washington, DC, 2018. Available from: https://data.worldbank.org/indicator/sh.imm.meas [accessed: January 5,2019$]$

[18] World Health Organization. Hungary: WHO and UNICEF estimates of immunization coverage: 2017 revision. Geneva, 2018. Available from: https://www.who.int/immunization/monitoring_surveillance/data/hun.pdf?ua $=1$ [accessed: 2019. January 05.].

[19] Ócsai L. Good expectations for the flu vaccine. 19 September 2018. [Az infuenzavakcinával szemben támasztott helyes elvárások. 2018. szeptember 19.] Available from: http:// otszonline.hu/cikk/az_influenzavakcinaval_szemben_tamasztott_helyes_elvarasok [accessed: January 5, 2019]. [Hungarian]

[20] Quick Reference. People's Movement January-April 2017. Significant excess mortality, increased natural population decline.
[KSH Gyorstájékoztató. Népmozgalom, 2017. január-április. Jelentős halálozási többlet, megnövekedett természetes fogyás.] Budapest. Közzététel: 2017. június 23. Available from: http:// www.ksh.hu/docs/hun/xftp/gyor/nep/nepl704.html [accessed: January 11, 2019]. [Hungarian]

[21] Lee SI, Aung EM, Chin IS, et al. Factors affecting medical students' uptake of the 2009 pandemic influenza A (HINl) vaccine. Influenza Res Treat. 2012; 2012: 753164.

[22] Abramson $\mathrm{ZH}$, Levi O. Is performance of influenza vaccination in the elderly related to treating physician's self immunization and other physician characteristics? Prev Med. 2008; 47: 550553.

[23] Yassi A, Lockhart K, Buxton JA, et al. Vaccination of health care workers for influenza: promote safety culture, not coercion. Can J Public Health 2010; 101(Suppl 1): S41-S45.

[24] Zhang J, While AE, Norman IJ. Knowledge and attitudes regarding influenza vaccination among nurses: a research review. Vaccine 2010; 28: 7207-7214

[25] Maurer J, Uscher-Pines L, Harris KM. Awareness of government seasonal and $2009 \mathrm{HINl}$ influenza vaccination recommendations among targeted US adults: the role of provider interactions. Am J Infect Control 2010; 38: 489-490.

[26] Constantino C, Mazzucco W, Azzolini E, et al. Influenza vaccination coverage among medical residents. An Italian multicenter survey. Hum Vaccin Immunother. 2014; 10: 1204-1210.

[27] Looijmans-Van den Akker I, Verheij TJ, Buskens E, et al. Clinical effectiveness of first and repeat influenza vaccination in adult and elderly diabetic patients. Diabetes Care 2006; 29: 1771-1776.

[28] Nichol KL, Baken L, Nelson A. Relation between influenza vaccination and outpatient visits, hospitalization, and mortality in elderly persons with chronic lung disease. Ann Intern Med. 1999; 130: 397-403.

[29] MacIntyre CR, Mahimbo A, Moa AM, et al. Influenza vaccine as a coronary intervention for prevention of myocardial infarction. Heart 2016; 102: 1953-1956. Available from: https://heart. bmj.com/content/102/24/1953/ [accessed: January 11, 2019].

[30] Lin HC, Chiu HF, Ho SC, et al. Association of influenza vaccination and reduced risk of stroke hospitalization among the elderly: a population-based case-control study. Int J Environ Res Public Health 2014; 11: 3639-3649.

(Fehér Ágnes dr., Budapest, Nagyvárad tér 4., 1089 e-mail: trombitasne.feher-agnes@med.semmelweis-univ.hu)

A cikk a Creative Commons Attribution 4.0 International License (https://creativecommons.org/licenses/by/4.0/) feltételei szerint publikált Open Access közlemény, melynek szellemében a cikk bármilyen médiumban szabadon felhasználható, megosztható és újraközölhető, feltéve, hogy az eredeti szerző és a közlés helye, illetve a CC License linkje és az esetlegesen végrehajtott módosítások feltüntetésre kerülnek. (SID_1) 